\title{
Yeni Mezun Mühendislerin Almış Oldukları Lisans Eğitimine ilişkin Görüşleri ve Mesleki Yeterlilik Algıları ${ }^{1}$
}

\begin{abstract}
Öz
Günümüz ekonomisi ve gelişim sürecindeki işletmeler; üretimde bilimsel yöntemlerin kullanılması, tüketim alışkanlıklarının değişmesi ve üretim çeşitliliğinin artmasının yanında, müşteri tercihlerinde meydana gelen değişimlere bağlı olarak, teknolojilerini sürekli geliştirip yeni ürünler üretmeye zorlanmıştır. Bu durum ortaya çıkan ihtiyacın karşılanmasında önemli bir faktör olan nitelikli insan gücü teminine yönelik talebi artırmıştır. Bu çalışmanın amacı; orta ve yükseköğretim döneminde verilen eğitimleri mezun mühendislerin bakış açıları ile değerlendirmektir. Çalışmanın evrenini 2017 yılında, Eskişehir ilinde çalışan mühendisler oluşturmaktadır. Anketler basit tesadüfí örnekleme yöntemiyle 142 mühendise uygulanabilmiştir. Anketin güvenilirlik oranı \%83'dür. Çalışmanın sonucunda mezun mühendislerin lisans döneminde aldıkları teorik ve uygulamalı eğitimlerle piyasaya ilk çıktıklarında zorlandıkları; belirli bir süre diğer çalışanlardan destek almak durumunda kaldıkları ve arzuladıkları pozisyonlarda çalışabilmek için ilave eğitim almaları gerektiğine inandıkları ortaya çıkmıştır.
\end{abstract}

Anahtar Kelimeler: Nitelikli İnsan Gücü, Mühendis, Müfredat, Faktör Analizi, Karşılaştırma Analizleri

\author{
Zeliha Kaygısız Ertuğ² \\ Emrah Göksel ${ }^{3}$
}

The Views of Newly Graduate Engineers' Regarding To The Undergraduate Education Received and Perceptions of Professional Competence

\section{Abstract}

Modern Economy and businesses have been forced to improve their technology and produce new products, depending on use of scientific method in manufacture, change of consumption habits and rise of manufacture multiplicity including change of customer options. This situation has increased qualified person demand, which is an important factor in fulfilment of this need. The intent of this study is to evaluate the education given during the middle and upper education period with the perspective of graduated engineers. The target population is consist of engineers who work in Eskisehir in 2017. Questionnaires could applied to 142 engineers. The reliability of the questionnaire was determined as \%83. It is detected that the graduated engineers have difficulty in the work place with the given education during the period of upper education when they first begin any work. Additionally, in a period of time they were forced to get help from another workers and believe that they need additional education in order to work in the better position they desired.

Keywords: Qualified Work Force, Engineer, Curriculum, Factor Analysis, Comparative Analysis

\section{Giriş}

Teknolojinin gelişmesi ile birlikte iletişim ve ulaşımın gelişip hız kazanması; yeni ürünleri tanıma, ürün seçimi, ürüne ulaşma ve ürünlerin ülkeler arasında serbest bir şekilde dolaşmasını kolaylaştırmıştır. Bu durum, yerli firmalar ve yerli firmalar ile yabancı firmalar arasında rekabete yol açmış, buna bağlı olarak da yenilik, ürün maliyetinin düşürülmesi, kalite ve çeşitliliğinin artırılması gibi pazarda tutunabilmeyi sağlayabilecek kavramların da önemi artmıştır.

\footnotetext{
${ }^{1}$ Bu çalışma, Eskişehir Osmangazi Üniversitesi Sosyal Bilimler Enstitüsü İşletme Anabilim Dalı’nda Doç.Dr.Zeliha Kaygısız Ertuğ danışmanlığında, Emrah Göksel tarafından tamamlanan ve 27.10.2017 tarihinde savunulan “Yeni Mezun Mühendislerin Sahip Olduğu Nitelik ve Yeterliliklerin Sanayi Sektörünün İhtiyaçları Temelinde İncelenmesi: Eskişehir İlinde ÇaIışan Mezun Mühendiler Üzerine Bir Uygulama" isimli yüksek lisans tezinden türetilmiştir.

2 Doç. Dr., Eskişehir Osmangazi Üniversitesi IïBF, İşletme Bölümü. zelihak@ogu.edu.tr, yazar ORCID bilgisi: https://orcid.org/0000-0003-1488-2377.

${ }^{3}$ Mezun Yüksek Lisans Öğrencisi, Eskişehir Osmangazi Üniversitesi, Sosyal Bilimler Enstitüsü, İşletme Ana Bilim Dalı. egoksel25@gmail.com, yazar ORCID bilgisi: https://orcid.org/0000-0002-7468-2986.
} 
Yenilik ve hayatı kolaylaştıran cihaz ve sistemler, insanların, ilk çağlardan itibaren gündeminde olmuştur. Üretimde ve günlük hayatta kullanılan alet, cihaz ve sistemler sanayi devrimine kadar sabit bir çizgide ve küçük çapta kullanılabilmiş, ağırlık yine insan gücünde olmuştur. Ancak, sanayi devrimi ile birlikte buharla çalışan büyük çaplı makine ve cihazların icat edilmesiyle, insan gücüne olan ihtiyaç azalmıştır; onlarca insan gücü kullanılarak belirli bir zamanda yapılabilen işler bir makineyle daha az zamanda yapılabilecek duruma gelmiştir. Bu durum insanlarda işsiz kalma endişesine yol açmış olsa da, buharlı makineler insandan daha ziyade, fizik ve emeğe dayalı insan gücüne olan gereksinimi azaltmıştır. Sanayi devrimi buharlı makinelerin icatlarıyla kalmamış, birbirini izleyen yeni teknolojik gelişmelerin de yolunu açmıştır. Gelişen yeni teknolojiler ile birlikte insana olan ihtiyaç yine önem kazanmıştır. Ancak bu önem, insanın beden gücünden ziyade, günümüzde nitelikli insan diye tanımladığımız, teknoloji ve yeni sistemlerle uyum içinde çalışabilen eğitimli insanlarla ilgili olmuştur; sanayi sektörünün beklentileri de yine nitelikli insan gücünün yetiştirilmesine yöneliktir.

Bir ülke veya bölgenin sanayileşmesi süreci, birbiriyle bağlantılı ve her biri kendi özelinde geniş bir zaman ve hazırlık aşamasına sahip süreçlere sahiptir. Bu süreçlerin başında, sanayileşecek bölgenin pazar yerlerine olan yakınlığı ve içeriğinde; bina, alt yapı, makine, cihaz ve teçhizatların olduğu yatırımlar gelmektedir. Bununla bağlantılı olarak ortaya çıkan yüksek yatırım maliyetleri sebebiyle sanayi sektörünün nitelikli çalışan ihtiyacı ve beklentileri önem kazanmaktadır. Bu anlamda gelişmiş sanayiler incelendiğinde nitelikli çalışan yetiştirme ve gelişim dengesinin iyi kurulduğu görülmektedir. Özetle denilebilir ki; yapılan yatırımların karşılık bulması birçok etkene bağlı olmasına karşın, bunların başında nitelikli insan gücünün sürece sunduğu katkı gelmektedir.

Nitelikli insan gücünü; bireyin ilgisi, istekleri, yeteneği ve piyasanın gereksinimleri doğrultusunda yeterli ve iyi eğitim almış, sisteme katkı sunmaya hazır insanlar olarak tanımlamak mümkündür. Bir sistem içerisindeki herhangi bir ürünün veya bir hizmetin planlanmasından pazarlanmasına kadar olan sürecin tamamında temel faktör insandır. Kaliteli ürün ve hizmetler, iyi bir eğitim sürecini gerekli kılmaktadır.

Tüm bu gelişmeler dikkate alınarak bir değerlendirme yapıldığında; mevcut eğitim ve müfredatın nitelikli insan gücü yetiştirmesindeki başarısının değerlendirilmesi ihtiyacı ortaya çıkmaktadır. Böyle bir değerlendirme için ülkemizdeki eğitim sisteminin ve işletmelerdeki reel durumun incelenmesi gerekmektedir.

Bu kapsamda işletmelerdeki mevcut durum incelendiğinde yeni mezunların, aldıkları teorik ve uygulamalı eğitimlerle yönetim veya üretim sürecine istenilen seviyede katkı sunamadıkları görülebilmektedir. Bu durum, yeni mezunların hazır olunabilirlik oranlarının istenilen seviyede olmadığını; işletme özelinde bir eğitime ihtiyaç duyduklarını göstermektedir. Bunun olası sebeplerini tespit edebilmek ve çözüm yolları ortaya koyabilmek için mevcut eğitim sisteminin nitelikli insan gücü yetiştirmedeki olumlu ve olumsuz yönlerini incelemek gerekmektedir. Piyasaya nitelikli insan gücü yetiştiren birçok orta ve yükseköğretim kurumu olmasına karşın, yapılmış olan bu çalışmanın merkezini; ekonominin omurgası durumunda olan ve nitelikli eleman yetiştirme açısından önemli kurumlar arasında bulunan mühendislik fakülteleri oluşturmaktadir.

Başta araştırma geliştirme faaliyetleri olmak üzere; problem çözme, üretim, tasarım, pazarlama, kalite, standartlaşma gibi ekonomi ve teknolojik gelişmişlik sürecinin temel parametreleri durumunda olan bu kavramlar temelde mühendis, tekniker ve teknisyen statüsünde bulunan çalışanların içinde bulundukları bir süreç ile ilgilidirler. Ancak sürecin genel yönlendirme ve 
kontrolü mühendis eliyle olmaktadır. Bu anlamda değerlendirildiğinde mühendislik fakültelerinin ve mühendislerin aldıkları eğitim, bakış açısı, tecrübe ve sürece hazır olunabilirlik seviyelerinin incelenmesi önem arz etmektedir.

Araştırılan konunun güncel ve üzerinde sürekli olarak değerlendirme yapılan bir alan olmasına bağlı olarak, konu hakkında ulusal ve uluslararası alanda birçok kitap, makale ve tez yazılmış olup konuyla doğrudan ilgili olabilecek çalışmalardan bazıları aşağıda açıklanmıştır. Bununla birlikte ulusal ve uluslararası alanda konuya yönelik yapılmış çalışmalar incelendiğinde ağırlıklı olarak; yükseköğretimde alınan eğitimin kalitesi, güncelliği ve çalışma sahasıyla uyumlu olup olmadığı hususlarının incelendiği görülmüştür. İncelenen bu konuların değerlendirilmesi ise iki farklı kaynaktan elde edilecek veriler ile mümkün olabilmiştir. Bu kaynaklardan biri; çalışmaya esas olan ve çalışma hayatına yeni başlamış mezunlar, diğeri ise, çalışan çalışanların etkinlik ve yeterliliğini ölçme konumunda bulunan işverenlerdir. Aşağıda hem mezun mühendislerden hem de işverenlerden elde edilen veriler doğrultusunda yapılmış çalışmalar açıklanmıştır. Bahse konu çalışmalarda ağırlıklı olarak; mühendislere, üniversitelere ve işverenlere yönelik önerilerde bulunulmuştur. Bu kapsamda, ulusal ve uluslararası literatür birlikte incelendiğinde;

Todd, Sorensen ve Magleby (1993), Amerika Birleşik Devletleri'nde bulunan Brigham Young Üniversitesi'nin; bünyesinde bulunan bazı mühendislik fakültelerinde başlattığı çeşitli çalışma ve programlar ile mühendislik fakültelerinde verilen eğitimlerin ve uygulanan programların sanayinin ihtiyaçlarına göre sürekli olarak güncellenmesini baz alarak, Amerikan imalat endüstrisinde ortaya çıkan bir takım problem ve gereksinimler ile bu problemlerin mühendislik eğitimi ile bağlantısını incelemiştir. Çalışmada ayrıca, mühendislik eğitimine yönelik olarak ortaya çıkan endüstriyel ihtiyaçlar tespit edilerek bu ihtiyaçlara yönelik olarak verilen eğitimlerde yapılması gereken değişiklikler ortaya konulmuştur. Çalışma sonunda, yukarıda bahsedilen mühendislik eğitimindeki değişiklikler ile ortaya çıkan yeni eğitim sürecinin sonuçları ve yansımaları tanımlanarak, öğrencilere, endüstriye ve üzerinde inceleme yapılan üniversitelere sağladığı faydalar açıklanmıştır. Çalışmada mühendislik fakültelerinin özetle; sanayi sektörünün hangi tip mezun istemediğini, verilen eğitimlerde nelerin değişmesini istedikleri, öğrencilere doğru şeyler öğretilip öğretilmediği, eğitim sürecinde harcanan zamanın uygun bir şekilde değerlendirilip değerlendirilmediği ve sanayi sektörüne etkin bir şekilde nasıl katkı sunulacağı gibi sorular çerçevesinde bir değerlendirme yapılarak, eğitim sistemlerini gözden geçirmeleri gerektiği vurgulanmıştır.

Elshorbagy ve Schönwetter (2002), American Society for Engineering Education, The Australian Journel of Engineering Education, The European Journel of Engineering Education ve The Internatioan Journel of Engineering Education gibi mühendislik eğitimi çerçevesinde yayınlanan dergilerin önerileri ve yönlendirmeleri üzerinde durmuştur. Çalışmada; hali hazırda uygulanmakta olan geleneksel mühendislik eğitimi yöntemi ve bu yöntemin meydana getirdiği zorluklar ele alınmıştır. Kolb'un bir numaralı öğrenme stili ve Bloom'un Bilişsel Sınıflandırma yöntemi temel alınarak geleneksel eğitim veren mühendislik fakültelerdeki eğitim müfredatının gelişimine yönelik çeşitli öneriler, mezun mühendislerin çalışma alında yaşadığı zorluklara yönelik yaptıkları değerlendirmeler çerçevesinde ele alınmıştır. Çalışma sonucunda; mühendislik fakültelerinin geleneksel eğitim yönteminden vazgeçemedikleri, sanayi ihtiyaçları ile verilen eğitimlerin arasındaki farkın devam ettiği, mezun mühendislerin okuldan uygulama sahasına geçerken zorlandıkları ve yeni mezun mühendislerin beklentilerden uzak bir şekilde eğitim almış olarak mezun olduğu sonuçları elde edilmiştir. 
Gençoğlu ve Gençoğlu (2005), Türkiye'de mühendislik eğitimi veren fakülte, bölüm ve tüm mühendislik programlarını inceleyerek öğrenci sayılarını tespit etmiştir. Bununla birlikte ülkemizde mühendislik eğitiminin kalitesi ve durumu incelenerek, başarı elde edilmesine yönelik tespitler yapılmıştır. Çalışma neticesinde; mühendislik niteliklerinin belirlenmesi, mühendislik kontenjanlarının ihtiyaca göre belirlenmesi, eğitime yeteri seviyede kaynak ayrılması, programa yönelik gerekli alt yapının hazırlanması gerektiği tespitleri yapılmıştır. Nihai başarının; bölümüne bilinçli bir tercih ve istek ile katılmış öğrenci ve çağın gereklerine göre kendisini yetiştirmiş idealist öğretim üyeleri ile gerçekleşebileceği vurgulanmıştır.

Besleme (2006), kimya mühendisliği bölümlerinde verilen eğitim ile sahada ihtiyaç duyulan bilgi arasında karşılaştırma yapmıştır. Çalışmaya esas teşkil eden veriler, oluşturulan bir örneklem neticesinde 246 kimya mühendisine yapılan anket ile toplanmıştır. Elde edilen veriler doğrultusunda yapılan analizler neticesinde; katılımcıların \%55,3'ü Matematik dersinin iş hayatında çok faydalı olduğunu bildirmiştir. Bununla birlikte katılımcılar, iş hayatında faydalı olma durumuna göre; Analitik \& Organik Kimya Laboratuvar dersi ile Genel Kimya dersi \%48,8, Malzeme Bilgisi dersi \%43,5 ve Termodinamik dersini \%40,2 oranında desteklemişlerdir.

Mustafa, Norkisme, vd. (2008), Malezya'da bulunan iki adet çok uluslu elektronik şirkette çalışmakta olan mühendisler üzerinde bir çalışma yapmıştır. Çalışmada, mühendislerin elektronik sektöründeki eğitim ve çalışma geçmişleri tanımlanarak, mühendislerin, mühendislik eğitimine, mesleğe ve işverene yönelik algıları tespit edilmeye çalışılmıştır. Elde edilen veriler; frekans, yüzde ve karşılaştırılabilir ortalama gibi tanımlayıcı istatistik teknikleri kullanarak analiz edilmiştir. Verilerin analizinde bağımsız $t$ testi ve tek yönlü ANOVA analizi kullanılmıştır. Çalışma neticesinde mühendislerin mühendislik eğitiminde; iletişim becerisi, liderlik ve yönetim yeteneklerinin kazandırılması gerektiğini büyük oranda desteklemişlerdir. Bununla birlikte mühendislik fakültesine başvuran öğrencilerin mesleğinin farkında ve her seviyedeki disiplinle iletişim kurabilecek yetenekte olması gerektiği vurgulanmıştır. Çalışmada mühendislerin işverenlerden görev başı eğitimlerinin artırılmasını ve önemsenmesini büyük oranda talep ettikleri de elde edilen sonuçlar arasındadır.

Sönmez (2011), mühendis ve mühendis yardımcılarının ömür boyu eğitim almaları kapsamında Meslek Yüksek Okullarının aldığı rolün incelenmesini ve eksikliklerin tespit edilmesini amaçlamıştır. Çalışma neticesinde yüksekokulların yeniden yapılandırılması gerekliliği üzerinde durulmuş, bunun yanı sıra da bünyesinde bulundukları üniversitelerin sürekli eğitim merkezlerinin görevini üstlenmesi gerektiği sonucuna varılmıştır.

Bloom, Saeki (2011), Hindistan'daki yeni mezun mühendislerin istihdam edilebilirlik ve yeteneklerine yönelik bir çalışma yapmıştır. Çalışma genelinde üç soruya cevap bulunmaya çalışılmıştır: İşverenler yeni mezun olmuş mühendisleri işe alırken adayların hangi yeteneklerini önemsemektedirler; işverenler mezun mühendislerin yeteneklerden ne derece memnunlar ve mühendisler hangi önemli yeteneklerden yoksundurlar. Çalışma neticesinde, iş yerlerine yeni mezun olmuş mühendisleri alan katılımcıların \%64'ünün yeni mühendislerin kalitesinden kısmen veya hiç memnun olmadıkları sonucu ortaya çıkmıştır. Çalışmanın konusunu oluşturan yeteneklerin faktör analizine tabi tutulması neticesinde işverenlerin temel istihdam edilebilirlik ve iletişim yeteneklerini daha çok önemsedikleri ortaya çıkmıştır. Çalışmada ayrıca yetenek eksikliklerinin daha çok, Bloom'un Sınıflandırma tekniğine göre sıralanmış üst düzey düşünme noktalarında ortaya çıktığı tespit edilmiştir. 
Yukarıda açıklanmış olan çalışmalar doğrudan mühendislere yönelik olup aynı bakış açısıyla ulusal ve uluslararası alanda diğer orta ve yükseköğretim kurumlarına yönelik yapılmış çalışmalar aşağıda açıklanmıştır. Yapılan bu çalışmalar genel anlamda değerlendirildiğinde, mühendislere yönelik yapılmış çalışmalar ile benzer konuların incelendiği görülmektedir. Bu kapsamda;

Haworth, Grant ve Clifton (1997), her seviyedeki yükseköğretim programlarını değerlendirmek ve geliştirmek için bir teori öne sürmektedir. Bu kapsamda Mastır programlarındaki 781 katılımcı ile mülakat yapılmıştır. Mülakat verileri temel alınarak öğrencinin gelişmesine ve öğrenmesine katkı sunabilecek yüksek kaliteli programlar geliştirilmesi üzerinde durulmuştur. Özellikle bu programların geliştirilmesine yönelik olarak öğrenci, fakülte ve yöneticilerin etkin bir katılımla katkı sunmalarının önemine değinilmiştir.

Bai (2006), mezun işsizler üzerinde yoğunlaşarak Çin'deki yükseköğretime katılımdaki artışın tarihsel ve sosyoekonomik şartlarını incelemiştir. Çalışmada, 1999 sonrasında alınan kararları gerekçeleri ve bu kararlarla birlikte büyüyen üçüncü seviye eğitim sektörünün toplum ve mezun işsizler üzerindeki etkileri araştırılmıştır. Martin Trow'un Çin'deki yükseköğretim sisteminin içerisinde bulunduğu ikilemler ve zorlukların analiz edildiği teorisi, bu çalışmanın temelini oluşturmuştur. Çalışmada yapılan incelemeler neticesinde Çin'deki eğitimin gelişmesi ile büyüyen ekonomi arasındaki ilişki sorgulanarak, eğitimin gelişme üzerinde etkisi olup olmadığı araştırılmıştır. Çalışmayla birlikte, Çin'de hızla artan eğitimli mezun işsizlerin durumuna bağlı olarak; ekonomik gelişmenin gözden geçirilmesi, eğitimde yeni politikalar geliştirilmesi ve yükseköğretim ile birlikte ekonomide reformlar yapılması gündeme gelmiştir.

İçli (2007), işletmelerin Meslek Yüksek Okulu mezunu çalışanları ile ilgili görüşlerini ortaya koyarak, Meslek Yüksek Okulu mezunlarından beklentilerinin neler olduğunu tespit etmeyi ve böylece Meslek Yüksek Okulu mezunlarının eğitim kalitesini artırmaya yönelik önerilerde bulunmayı amaçlamıştır. Belirlenen işletmelere yönlendirilmek üzere üç farklı anket hazırlanmıştır. Anketler yoluyla elde edilen verilerin karşılaştırılmasında Kolmogorov-Simirnov ve Kuruskal Wallis testleri ve varyans analizi kullanılmıştır. Elden edilen bulgular; işletmelerin, mezunların çalışma ahlaklarından memnun olduklarını gösterse de, gerekli olan yabanca dil seviyesi noktasında yetersiz kaldıkları ve eğitim kurumlarının sanayi ile işbirliği içinde olmaları gerektiği yönünde görüşler ortaya konulmuştur.

Lin (2008), Çin'de verilen muhasebe eğitimini inceleyerek tespit edilen eksikliklerin düzeltilmesi ve geliştirilmesine yönelik olarak çözüm önerileri sunmayı ve bunları Çin ve başka ülkelerle paylaşmayı amaçlamıştır. Bu çalışma, faktör analizini kullanarak, değişen piyasa şartlarından kaynaklı zorlukları aşmak için muhasebe eğitimi içerisinde vurgulanması gereken ve aynı zamanda arzu edilen eğitim ve yetenek bileşenleri ile ilgili deneysel olarak 6 yapı geliştirmiştir. Muhasebe eğitimi içerisindeki bilgi ve tecrübe gereksiniminin bu altı boyutunun yapısal sıralaması (hiyerarşisi) faktör yükleme sonuçlarına dayanarak elde edilmeye çalışılmıştır. Çalışma neticesinde elde edilen bulgular dâhilinde; klasik muhasebe eğitiminin gelişen küresel ekonomi ve ileri teknoloji destekli üretimler sebebiyle yenilenmeye ve geliştirilmeye ihtiyaç duyduğu vurgulanmıştır. Yeni muhasebe eğitimlerinin sonradan ortaya çıkan bilgi ve deneyimler çerçevesinde geliştirilmesi gerektiği sonucuna varılmıştır.

Göral (2008), meslek eğitim merkezlerinde verilen eğitimin genel bir değerlendirmesini hedeflediği çalışmasında, işveren ve okula devam eden öğrencilerin beklentilerini belirlemeyi ve karşılaştıkları sorunları ortaya koyarak çözümler sunmayı amaçlamıştır. Hazırlanan iki farklı anket, Anadolu Yakasında bulunan 200 Meslek Eğitim Merkezi öğrencisine ve 170 işverene uygu- 
lanmıştır. Araştırmada yaş, kıdem, mezun olunan okul türü, çalıştırılan personel sayısı ve cinsiyet gibi değişkenlere göre bulgular değerlendirilmiştir. İkili grupların karşılaştırılmasında t testi, üçlü ve fazla grupların karşılaştırılmasında ise tek yönlü varyans analizi yapılmıştır. Varyans analizinde istatistiksel olarak anlamlı bulunan gruplarda, anlamlı farklılığa neden olan kaynağı (alt grupları) tespit etmek için post hoc test (Scheffe) uygulanmıştır. Elden edilen bazı önemli bulgular; karşılıklı bilgi aktarımı için yeteri seviyede toplantı yapılmadığını, öğrencilerin okulda öğrendiklerini uygulamada orta seviyede olduklarını göstermiştir. İşverenlerin meslek eğitim merkezlerinde verilen eğitim süresini, kendi meslek dalları açısından yeterli buldukları da ulaşılan sonuçlar arasındadır.

Durak (2009), üniversitelerde verilen muhasebe eğitiminin küçük ve orta büyüklükteki işletmelerin beklentilerini karşılama düzeyinin incelenmesini amaçlamıştır. Literatür taraması sonucunda ulaşılan bilgiler değerlendirilerek, uygulama aşamasında elde edilen veriler uygun istatistiksel araçlar kullanılarak analize tabi tutulmuştur. Araştırmanın bulguları; İşletmelerin muhasebe kayıtlarını tutan elemanların üniversite öğrenimi sırasında aldıkları muhasebe eğitimini yeterli düzeyde bulup bulmadıklarının dağılımı incelendiğinde; ön lisans öğrenimi görenlerin \%40’ genel bir bilgi, \%36'sı zayıf bir bilgi, \%12'si tam ve yeterli bir bilgi, lisans öğrenimi görenlerin \%52'si genel bir bilgi, \%36'sı zayıf bir bilgi, \%12'si tam ve yeterli bir bilgi edindiklerini bildirmişlerdir.

Düzakın ve Yılmaz (2009), Türkiye'de önde gelen sanayi firmalarını işletme eğitiminin yeterlilik düzeyi, müfredat etkinliği ve sosyal yararlılığı gibi ölçütler açısından değerlendirerek, işletme mezunlarının iş hayatındaki durumlarıyla aralarında anlamlı ilişki olup olmadığının saptanması; eğer varsa bu ilişkinin yorumlanmasını amaçlamışlardır. Elde edilen verilerin değerlendirilmesinde, Microsoft Office Excel ve SPSS programından yararlanılmıştır. Excel de oransal analizler yapılmıştır. SPSS programında ise frekans ve tanımlayıcı analizlerden yardım alınarak sonuçlar elde edilmiştir. Elde edilen bulgulara göre; işletmelerde çalışan ortalama 30 üniversite mezununun sadece $8^{\prime} i$ işletmecidir. Firmalar işletme mezunlarını yöneticilik açısından yetersiz bulmaktadırlar. Firmalar işletme mezunlarının; pratik yönetim, uygulamalı iş idaresi ve örnek olaylar üzerinde eğitim almalarını istemektedirler.

Massie, Strang, vd. (2009), işverenlerin; başlangıç seviyesindeki sertifikalı spor eğitmenlerinin akademik performansına yönelik memnuniyetlerini belirlemeye ve müfredat yetersizliğine yönelik algılamaları tespit etmeye çalışmıştır. Çalışmaya esas teşkil eden veriler, bir online anketin işverenlere uygulanmasıyla elde edilmiştir. Anketler 1716 işverene gönderilmesine karşın, işverenlerin sadece 104'ü ankete cevap vermiştir. Çalışma sonucunda işverenler; başlangıç seviyesindeki sertifikalı eğitmenlerin, mesleklerine yönelik hem akademik hem de klinik olarak yeterli seviyede olduklarını belirtmişlerdir; ancak, eğitmenlerin, çevreleriyle bireysel ve bire bir iletişime geçme noktasında öğrencilerine daha fazla fırsat vermeleri gerektiğini vurgulamışlardır.

Altın, Uğur vd. (2010), İnşaat Programı müfredatının, laboratuvar uygulamalarının, öğretim elemanlarının ve MYO fiziki donanımlarının öğrenciler tarafından nasıl değerlendirildiğini belirlemeyi amaçlamışlardır. İnşaat Programı son sınıf öğrencilerinden 54 kişiye uygulanan bir anket neticesinde elde edilen veriler, oluşturulan frekans ve yüzdelik ifadelerin belirtildiği tablo ve grafikler yardımı ile değerlendirilmiştir. Elde edilen bulgulara göre; İnşaat Teknolojisi Programı öğrencileri, İnşaat Teknikerliği eğitiminde verilen derslerden en çok "Bilgisayar Destekli Tasarım" dersinden fayda göreceklerini düşünmektedirler. Öğrenciler "Çelik Yapılar", "Su Temini ve 
Atık Sular" ve "Topografya" derslerini en çok fayda görecekleri dersler arasında düşünmeyerek, sıralamada daha aşağılarda yer vermişlerdir.

Ulusal ve uluslararası alanda bu çalışmanın konusuna yönelik pek çok çalışma yapılmış olmasına karşın, orta öğretimde mesleki eğitim almış mühendisler ile alana yönelik olarak herhangi bir eğitim almamış mühendislerin karşılaştırıldığı bir çalışmaya rastlanılmamıştır. Bununla birlikte bu çalışmada, çeşitli mühendislik fakültelerinden mezun olmuş mühendislerin belirlenen konulara yönelik tecrübe ve görüşleri karşılaştırılarak anlamlı farklılık olup olmadığı; farklılık gösteren hususların ise nedenleri araştırılmıştır. Yapılan bu çalışma ile yukarıda bahsedilen literatür boşluklarının doldurulmasına katkı sunulması ve bu alana yönelik olarak yeni ve daha kapsamlı çalışmaların yapılmasına öncü olunması hedeflenmektedir. Ayrıca bu çalışmada orta ve yükseköğretim döneminde verilen eğitimler, mezun mühendislerin bakış açıları ile değerlendirilmiştir. Bununla birlikte, alınan eğitimler ile bağlantılı olarak mezun mühendislerin piyasada ne derece karşılık bulduklarını ve karşılaştıkları zorluk ve edindikleri tecrübelere dayalı görüşlerini tespit etmek; bulgulara göre anlamlı öneriler ortaya koymak, çalışmanın amaçları arasındadır. Bu kapsamda çalışmada belirlenen sorunlara yönelik olarak elde edilen bulgular doğrultusunda çözüm önerileri üretilmeye çalışılmıştır. Yapılan bu çalışma, ülke ekonomisinde önemli bir yeri olan eğitim ve zaman kaynaklarının verimli bir şekilde kullanılması ve eğitimdeki etkinliğin artırılmasına yönelik çözüm önerileri sunması itibariyle önem arz etmektedir.

\section{Araştırmanın Yöntemi}

Bu çalışmada, Eskişehir ilinde faaliyet gösteren kurum, kuruluş ve işletmelerde çalışmakta olan mezun mühendislere yönelik bir uygulama yapılmıştır. Uygulama kapsamında, verilerin toplanmasına yönelik olarak mühendislere anket uygulaması yapılmıştır. Mezun mühendislerin orta öğretim ve lisans döneminde aldıkları eğitimlerle piyasa ortamında ne derece karşılık bulduklarının ölçülmesine yönelik olarak hazırlanmış olan 24 maddelik anket ilk aşamada faktör analizine tabi tutulmuş, faktör yükü \%50'in altında olan maddeler ile tek faktör altında toplanan maddeler anketten çıkartılmıştır. Geriye kalan 18 maddelik ölçeğin tekrar faktör analizine tabi tutulması sonucunda anketi oluşturan maddeler 5 faktör altında gruplandırılmıştır.

Faktör analizi sonucunda belirlenen faktörler bakımından katılımcıların çeşitli demografik özelliklere göre farklılıklarının analizinde cinsiyet, mezun olunan lise türü ve çalışma alanı gibi iki gruba yönelik karşılaştırmalarda bağımsız örneklemler $t$ testi uygulanmıştır. Mezun olunan mesleki lise alanı ve lisans bölümü gibi ikiden fazla grubun alt ölçek puan ortalamalarının karşılaştırılmasında ise ANOVA kullanılmıştır. Farklılı̆ın anlamlı bulunması durumunda, farklııı̆a neden olan grupların belirlenmesi amacıyla çoklu karşılaştırma testi (Tukey Testi) uygulanmıştır. Çalışmada yapılan tüm istatistiksel analizlerde anlam düzeyi \%5 olarak alınmış ve SPSS 20.0 paket programından yararlanılmıştır.

\subsection{Araştırma Evreni ve Örneklem}

Çalışmanın evrenini Eskişehir ilinde çalışan mühendisler oluşturmaktadır. Anketler basit tesadüfî örnekleme yöntemine göre ulaşılabilen 142 mühendise uygulanabilmiştir.

\subsection{Veri Toplama Aracı}

Veriler, araştırma evrenine yönelik olarak oluşturulan örneklem kapsamındaki mühendislere bir anket uygulanarak toplanmıştır. Anketin güvenilirliği 142 anket üzerinde test edilmiş ve güvenilirlik oranı \%83 olarak tespit edilmiştir. Uygulanan anket, Orta Doğu Teknik Üniversitesi (ODTÜ) Çevre Mühendisliği Fakültesinin, mezunlarına yönelik olarak hazırlamış olduğu anketten uyarlanarak hazırlanmıştır. Anket soruları, mühendislik fakültesi mezunlarının okul döneminde 
aldıkları teorik ve uygulamalı eğitimlerle işletmelerde ne derece karşılık bulabildiklerinin tespitine yönelik olarak hazırlanmıştır.

\subsection{Verilerin Analizi}

Verilerin analizi aşamasında, mezun mühendislerin çalışma hayatında edindikleri tecrübe ve karşılaştıkları zorlukları esas alarak okul döneminde aldıkları teorik ve uygulamalı eğitimlerin etkinliği ölçülmeye çalışılmıştır. Elde edilen verilerin değerlendirilmesinde faktör analizi ve karşılaştırma analizleri (t testi, varyans analizi) kullanılmıştır.

\subsection{Bulgular}

Araştırmaya katılan mühendislere uygulanan anket sonucunda ortaya çıkan demografik özelliklere yönelik dağılım Tablo 1'de verilmiştir.

Tablo 1: Ankete Katılanların Demografik Özelliklerine Göre Dağılımı

\begin{tabular}{llcc}
\hline Değişkenler & Değişken Düzeyleri & Sayı & Yüzde \\
\hline \hline \multirow{2}{*}{ Cinsiyet } & Erkek & 122 & 85,9 \\
& Kadın & 20 & 14,1 \\
Mezun Olunan Lise Türü & Mesleki Eğitim Veren Lise & 28 & 19,7 \\
& Fen/Anadolu/ Anadolu Öğretmen Lisesi & 114 & 80,3 \\
& Elektrik & 5 & 17,9 \\
& Elektronik & 8 & 28,6 \\
Mezun Olunan Mesleki Lise Alanı & Makine & 7 & 25,0 \\
& Bilgisayar & 2 & 7,1 \\
& Diğer & 6 & 21,4 \\
& Elektrik Mühendisliği & 10 & 7,0 \\
& Elektronik Mühendisliği & 2 & 1,4 \\
& Makine Mühendisliği & 58 & 40,8 \\
Mezun Olunan Lisans Bölümü & Inşaat Mühendisliği & 10 & 7,0 \\
& Bilgisayar Mühendisliği & 2 & 1,4 \\
& Endüstri Mühendisliği & 8 & 5,6 \\
& Elektrik Elektronik Mühendisliği & 38 & 26,8 \\
& Diğer & 14 & 9,9 \\
& İare ve Yönetim & 55 & 38,7 \\
\hline
\end{tabular}

Tablo 1 incelendiğinde, araştırmaya katılan mezun mühendislerin \%85,9'unun erkek, $\% 14,1^{\prime}$ inin kadın olduğu görülmektedir. Mezun olunan lise türü incelendiğinde ise, katılımcıların $\% 19,7$ 'sinin mesleki eğitim veren bir liseden, \%80,3'ünün ise Fen/Anadolu/Anadolu Öğretmen Lisesi vb.'den mezun olduğu anlaşılmaktadır. Ankete katılanların \%19,7'sini oluşturan mesleki eğitim veren bir liseden mezun olan mezunların orta öğretimden mezun oldukları bölümler incelendiğinde, \%17,9'unun Elektrik, \%28,6'sının Elektronik, \%25'inin Makine, \%7,1'inin Bilgisayar ve \%21,4'ünün ise diğer bölümlerden mezun olduğu görülmektedir. Mezun olunan lisans bölümü incelendiğinde ise mezunların, \%7'sinin Elektrik Mühendisliği, \%1,4'ünün Elektronik Mühendisliği, \%40,8'inin Makine Mühendisliği, \%7'sinin İnşaat Mühendisliği, \%1,4'ünün Bilgisayar Mühendisliği, \%5,6'sının Endüstri Mühendisliği, \%26,8'inin Elektrik Elektronik Mühendisliği ve $\% 9,9$ 'unun ise diğer mühendislerden oluştuğu görülmektedir. Ankete katılan mühendislerin yaklaşık olarak \%66'sını Makine ve Elektrik Elektronik Mühendislerinin oluşturması; Eskişehir'deki sanayi yapısıyla açıklanabilir. Çalışma alanı incelendiğinde ise katılımcıların \%38,7'sinin idare ve yönetimde, \%61,3'ünün ise üretim alanında çalıştığı anlaşılmaktadır.

Mezun mühendislerin orta öğretim ve lisans döneminde aldıkları eğitimlerle piyasa ortamında ne derece karşılık bulduklarının ölçülmesine yönelik olarak hazırlanmış olan 24 maddelik 
ölçek ilk aşamada faktör analizine tabi tutulmuş, faktör yükü \%50'in altında olan maddeler ile tek faktör altında toplanan maddeler ölçekten çıkartılmıştır. Geriye kalan 18 maddelik ölçeğin tekrar faktör analizine tabi tutulması sonucunda 5 faktör altında gruplandırılan veriler Tablo 2 'de verilmiştir. Bartlett Testi sonucu 988,343(p<0.05) olarak, Kaiser-Meyer-Olkin örneklem değeri ise 0,859 olarak ölçülmüştür ki bu değer kabul edilebilir sınırlar içerisindedir. Ölçeğin güvenilirliği ise \% 83'dür (Cronbach alpha= 0,83 ).

Faktör analizi sonucunda belirlenen 5 faktörden birincisi varyansın \%26,611'ini, ikinci faktör $\% 11,868$ 'ini, üçüncü faktör $\% 10,447$ 'sini, dördüncü faktör $\% 8,258$ 'ini ve beşinci faktör ise $\% 7,298$ 'ini oluşturmaktadır. Belirlenen 5 faktörün toplam varyans açıklama oranı ise \%64,482'dir. Belirlenen faktörlerden birincisi “Eğitim Etkinliği”, ikincisi “iletişim”, üçüncüsü "Bilinçli Tercih", dördüncüsü "Yeterlilik" ve beşincisi ise "Gelir ve Yeterlilik" olarak isimlendirilmiştir (Tablo 2).

Tablo 2: Faktör Analizi Sonuçları

\begin{tabular}{|c|c|c|c|}
\hline TUTUM FAKTÖRLERi & $\begin{array}{l}\text { Fak- } \\
\text { tör } \\
\text { Yükü }\end{array}$ & A.Var. & K.Var. \\
\hline Faktör 1: Eğitim Etkinliği & & 26,61 & 26,61 \\
\hline İfade19: Bölümümdeki eğitim müfredatı, işyerimdeki sorunları çözmemde yardımcı olmaktadır. & 0,76 & & \\
\hline Iffade8: Aldığım teorik ve uygulamalı eğitimin yeterli olduğunu düşünüyorum. & 0,75 & & \\
\hline Iffade6: Aldığım eğitim, şimdiki görevimin gereksinimleri için beni hazırladı. & 0,74 & & \\
\hline $\begin{array}{l}\text { Ifade14: Çalıştığım işletmelerdeki faaliyetler için gerekli olan teorik ve uygulama bilgisini bölümümde } \\
\text { aldım. }\end{array}$ & 0,72 & & \\
\hline Iffade9: Bölümümde aldığım eğitim başlangıçtaki eğitim beklentimi karşıladı. & 0,69 & & \\
\hline $\begin{array}{l}\text { Iffade4: Çalıştığım işletmede bulunan yeni teknoloji ürünü makine, teçhizat ve sistemlerle ilgili olarak } \\
\text { bölümümde aldığım eğitim yeterli seviyededir. }\end{array}$ & 0,66 & & \\
\hline $\begin{array}{l}\text { Ifade11: Aldığım eğitim sayesinde piyasada maddi ve manevi tatmin sağlayabilecek bir işi kolayca bu- } \\
\text { labildim. }\end{array}$ & 0,66 & & \\
\hline Ifade7: Bölümümün akademik kalitesi yeterli seviyededir & 0,64 & & \\
\hline İfade16: Çalıştığım işletmelerdeki yöneticilerim, aldığım eğitimi yeterli bulmaktadır. & 0,57 & & \\
\hline Faktör 2: Illetişim & & 11,87 & 38,48 \\
\hline İfade17: Eğitimim sırasında, disiplinler arası gruplarda çalışabilme yetisi edindiğimi düşünüyorum & 0,85 & & \\
\hline İfade18: Eğitimim sırasında, etik sorumluluk anlayışları edindiğimi düşünüyorum & 0,82 & & \\
\hline Ifade15: Aldığım eğitim ile iletişim kabiliyetimi geliştirdiğimi düşünüyorum. & 0,60 & & \\
\hline Faktör 3: Bilinçli Tercih & & 10,45 & 48,93 \\
\hline ifade2: Mesleğin özellikleri ve içeriği hakkında daha önceden fikrim vardı. & 0,87 & & \\
\hline İfade1: Bölümüme bilinçli bir tercihle girdim. & 0,86 & & \\
\hline Faktör 4: Yeterlilik & & 8,26 & 57,18 \\
\hline $\begin{array}{l}\text { ifade10: Çalışmaya ilk başladığımda belirli bir süreyle uygulama alanında çalışmakta olan (Ustabaşı, } \\
\text { Usta vs.) personelden yardım almak durumunda kaldım. }\end{array}$ & 0,77 & & \\
\hline $\begin{array}{l}\text { Ifade24: Daha iyi işletme ve pozisyonlarda çalışmam için bölümümde aldığım eğitimin yanı sıra ilave } \\
\text { bir eğitim almam gerektiğine inanıyorum. }\end{array}$ & 0,73 & & \\
\hline Faktör 5: Gelir ve Yeterlilik & & 7,30 & 64,48 \\
\hline $\begin{array}{l}\text { İfade23: Çalıştığım işyerindeki maaşım bir mühendis için yeterli değildir. } \\
\text { İfade20: Orta öğretim (lise) döneminde ilgili yükseköğretim alanına yönelik olarak temel uygulamalı }\end{array}$ & 0,75 & & \\
\hline ve teorik dersleri almak yükseköğretimdeki başarıyı artıracaktır. & 0,66 & & \\
\hline
\end{tabular}

Cinsiyet, mezun olunan lise türü ve çalışma alanı bakımından belirlenen faktörlere yönelik tutum farklılığı olup olmadığı bağımsız örneklemler $t$ testi ile test edilmiş ve sonuçlar Tablo 3 , Tablo 4 ve Tablo 5'de verilmiştir. 
Eskişehir Osmangazi Üniversitesi iißBF Dergisi

Tablo 3: Cinsiyete Göre Alt Ölçeklerin Bağımsız Örneklemler t Testi Sonuçları

\begin{tabular}{|c|c|c|c|c|c|c|c|c|}
\hline & & \multicolumn{2}{|c|}{ Levene Testi } & \multicolumn{5}{|c|}{ t Testi } \\
\hline & & $\mathbf{F}$ & $\mathbf{p}$ & $\mathbf{t}$ & s.d. & p & $\begin{array}{l}\text { Ortalama } \\
\text { Fark }\end{array}$ & Std.Hata \\
\hline \multirow{2}{*}{ 占溤 } & Varyanslar Eşit & 1,03 & 0,311 & $-1,333$ & 140 & 0,185 & $-0,3207$ & 0,2405 \\
\hline & Varyanslar Eşit Değil & & & $-1,229$ & 24,22 & 0,231 & $-0,3207$ & 0,2610 \\
\hline \multirow{2}{*}{ 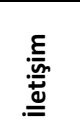 } & Varyanslar Eşit & 0,07 & 0,793 & $-0,696$ & 140 & 0,488 & $-0,1682$ & 0,2416 \\
\hline & Varyanslar Eşit Değil & & & $-0,716$ & 26,21 & 0,480 & $-0,1682$ & 0,2348 \\
\hline \multirow{2}{*}{ 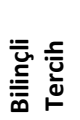 } & Varyanslar Eşit & 0,05 & 0,832 & 1,088 & 140 & 0,278 & 0,2623 & 0,2410 \\
\hline & Varyanslar Eşit Değil & & & 1,123 & 26,27 & 0,272 & 0,2623 & 0,2336 \\
\hline \multirow{2}{*}{$\begin{array}{l}\text { 兰 } \\
\frac{\bar{Z}}{d} \\
\stackrel{ \pm}{ \pm}\end{array}$} & Varyanslar Eşit & 0,47 & 0,496 & 2,067 & 140 & 0,041 & 0,4930 & 0,2384 \\
\hline & Varyanslar Eşit Değil & & & 1,842 & 23,73 & 0,078 & 0,4930 & 0,2676 \\
\hline \multirow{2}{*}{ 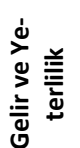 } & Varyanslar Eşit & 6,86 & 0,010 & 0,292 & 140 & 0,770 & 0,0707 & 0,2420 \\
\hline & Varyanslar Eşit Değil & & & 0,430 & 41,40 & 0,669 & 0,0707 & 0,1644 \\
\hline
\end{tabular}

Tablo 3'e göre sadece yeterlilik alt ölçeği bakımından cinsiyete göre erkek ve kadın mezunlar arasındaki fark anlamlı bulunmuştur (yeterlilik boyutu için ortalama fark=0,49303909 ve $p=$ 0.041). Bu anlamlı fark, erkek mezunların kadın mezunlara göre yeterliliğe yönelik daha kararlı bir tutum içerisinde olduklarını göstermektedir.

Tablo 4: Mezun Olunan Liseye Göre Alt Ölçeklerin Bağımsız Örneklemler t Testi Sonuçları

\begin{tabular}{|c|c|c|c|c|c|c|c|c|}
\hline & & \multicolumn{2}{|c|}{ Levene Testi } & \multicolumn{5}{|c|}{ t Testi } \\
\hline & & $\mathbf{F}$ & $\mathbf{p}$ & $\mathbf{t}$ & s.d. & p & $\begin{array}{c}\text { Ortalama } \\
\text { Fark }\end{array}$ & $\begin{array}{l}\text { Std. } \\
\text { Hata }\end{array}$ \\
\hline \multirow{2}{*}{ 占澏 } & Varyanslar Eşit & 1,53 & 0,219 & 0,228 & 140 & 0,820 & 0,0483 & 0,2116 \\
\hline & Varyanslar Eşit Değil & & & 0,247 & 45,86 & 0,806 & 0,0483 & 0,1954 \\
\hline \multirow{2}{*}{ 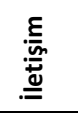 } & Varyanslar Eşit & 3,38 & 0,068 & $-2,899$ & 140 & 0,004 & $-0,5960$ & 0,2055 \\
\hline & Varyanslar Eşit Değil & & & $-2,680$ & 37,88 & 0,011 & $-0,5960$ & 0,2224 \\
\hline \multirow{2}{*}{ 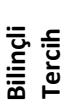 } & Varyanslar Eşit & 1,25 & 0,266 & 3,273 & 140 & 0,001 & 0,6676 & 0,2040 \\
\hline & Varyanslar Eşit Değil & & & 3,662 & 48,19 & 0,001 & 0,6676 & 0,1823 \\
\hline \multirow{2}{*}{ 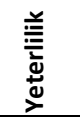 } & Varyanslar Eşit & 0,01 & 0,943 & 0,271 & 140 & 0,787 & 0,0572 & 0,2116 \\
\hline & Varyanslar Eşit Değil & & & 0,260 & 39,49 & 0,796 & 0,0572 & 0,2200 \\
\hline \multirow{2}{*}{ 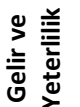 } & Varyanslar Eşit & 0,01 & 0,927 & 1,550 & 140 & 0,123 & 0,3252 & 0,2098 \\
\hline & Varyanslar Eşit Değil & & & 1,564 & 41,75 & 0,125 & 0,3252 & 0,2080 \\
\hline
\end{tabular}


Tablo 4 incelendiğinde, mezun olunan lise türüne göre iletişim ve bilinçli tercih alt ölçekleri bakımından mesleki eğitim veren lise ve Fen/Anadolu/Anadolu Öğretmen Lisesi vb. arasındaki fark anlamlı bulunmuştur (iletişim boyutu için ortalama fark=-0,59602464 ve $p=0,004$, bilinçli tercih boyutu için ortalama fark=0,66765897 ve $p=0,001$ ). Bu anlamlı fark, iletişim boyutu açısından Fen/Anadolu/Anadolu Öğretmen Lisesi vb. liselerinden mezun olan katılımcıların mesleki eğitim veren bir liseden mezun olan katılımcılara göre daha kararlı bir tutum içerisinde olduklarını göstermektedir. Bilinçli tercih boyutunda ise, mesleki eğitim veren bir liseden mezun olan katılımcıların Fen/Anadolu/Anadolu Öğretmen Lisesi vb. liselerinden mezun olan katılımcılara göre daha kararlı bir tutum içerisinde olduklarını göstermektedir.

Tablo 5: Çalışma Alanına Göre Alt Ölçeklerin Bağımsız Örneklemler t Testi Sonuçları

\begin{tabular}{|c|c|c|c|c|c|c|c|c|}
\hline & & \multicolumn{2}{|c|}{ Levene Testi } & \multicolumn{5}{|c|}{ t Testi } \\
\hline & & $\mathbf{F}$ & $\mathbf{p}$ & $\mathbf{t}$ & s.d. & $\mathbf{p}$ & $\begin{array}{c}\text { Ortalama } \\
\text { Fark }\end{array}$ & $\begin{array}{l}\text { Std. } \\
\text { Hata }\end{array}$ \\
\hline \multirow{2}{*}{ 澈 } & Varyanslar Eşit & 1,40 & 0,239 & 0,349 & 140 & 0,728 & 0,0602 & 0,1728 \\
\hline & Varyanslar Eşit Değil & & & 0,360 & 126,27 & 0,720 & 0,0602 & 0,1675 \\
\hline \multirow{2}{*}{ 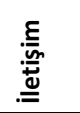 } & Varyanslar Eşit & 2,65 & 0,106 & $-1,432$ & 140 & 0,154 & $-0,2458$ & 0,1716 \\
\hline & Varyanslar Eşit Değil & & & $-1,375$ & 99,91 & 0,172 & $-0,2458$ & 0,1787 \\
\hline \multirow{2}{*}{ 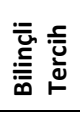 } & Varyanslar Eşit & 0,29 & 0,594 & $-1,131$ & 140 & 0,260 & $-0,1946$ & 0,1720 \\
\hline & Varyanslar Eşit Değil & & & $-1,097$ & 103,68 & 0,275 & $-0,1946$ & 0,1773 \\
\hline \multirow{2}{*}{$\stackrel{\stackrel{ \pm}{ \pm}}{\stackrel{ \pm}{ \pm}}$} & Varyanslar Eşit & 2,69 & 0,103 & $-1,762$ & 140 & 0,080 & $-0,3013$ & 0,1709 \\
\hline & Varyanslar Eşit Değil & & & $-1,683$ & 98,03 & 0,095 & $-0,3013$ & 0,1790 \\
\hline \multirow{2}{*}{ 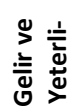 } & Varyanslar Eşit & 0,23 & 0,636 & 0,161 & 140 & 0,872 & 0,0278 & 0,1728 \\
\hline & Varyanslar Eşit Değil & & & 0,164 & 122,48 & 0,870 & 0,0278 & 0,1694 \\
\hline
\end{tabular}

Tablo 5 incelendiğinde ise tüm alt ölçeklerde çalışma alanına göre idare/yönetim ve üretim alalarında çalışan mezunların tutumları açısından aralarında anlamlı bir fark bulunmamaktadır. Diğer bir ifadeyle mezunların belirlenen ölçeklere yönelik tutumlarında çalışma alanı bakımından anlamlı bir farklılık olmadığı \%95 güvenilirlikle söylenebilir.

Katılımcıların \%19,7'sini oluşturan mesleki eğitim veren bir liseden mezun olan çalışanların mezun oldukları mesleki lise alanına göre belirlen faktörlere yönelik tutumlarının farklılık gösterip göstermediğini tespiti için ANOVA testi uygulanmış, sonuçlar Tablo 6'da açıklanmıştır. Buna göre mezun olunan mesleki lise alanına göre belirlenen faktörlere karşı herhangi bir tutum farklılığının olmadığı görülmektedir. 
Eskişehir Osmangazi Üniversitesi ïBF Dergisi

Tablo 6: Mezun Olunan Mesleki Lise Alanına Göre Tek Yönlü ANOVA Sonuçları

\begin{tabular}{|c|c|c|c|c|c|c|}
\hline Faktörler & Varyans Kaynağı & Kareler Toplamı & s.d. & $\begin{array}{c}\text { Kareler Orta- } \\
\text { laması }\end{array}$ & $\mathrm{F}$ & $p$ \\
\hline \multirow{3}{*}{ Eğitim Etkinliği } & Gruplar Arası & 3,111 & 4 & 0,778 & 0,952 & 0,452 \\
\hline & Gruplar İçi & 18,792 & 23 & 0,817 & & \\
\hline & Toplam & 21,902 & 27 & & & \\
\hline \multirow{3}{*}{ İletişim } & Gruplar Arası & 1,935 & 4 & 0,484 & 0,377 & 0,823 \\
\hline & Gruplar İçi & 29,506 & 23 & 1,283 & & \\
\hline & Toplam & 31,441 & 27 & & & \\
\hline \multirow{3}{*}{ Bilinçli Tercih } & Gruplar Arası & 2,115 & 4 & 0,529 & 0,741 & 0,574 \\
\hline & Gruplar İçi & 16,420 & 23 & 0,714 & & \\
\hline & Toplam & 18,536 & 27 & & & \\
\hline \multirow{3}{*}{ Yeterlilik } & Gruplar Arası & 3,218 & 4 & 0,805 & 0,688 & 0,607 \\
\hline & Gruplar İçi & 26,886 & 23 & 1,169 & & \\
\hline & Toplam & 30,104 & 27 & & & \\
\hline \multirow{3}{*}{ Gelir ve Yeterlilik } & Gruplar Arası & 2,642 & 4 & 0,661 & 0,647 & 0,634 \\
\hline & Gruplar İçi & 23,466 & 23 & 1,020 & & \\
\hline & Toplam & 26,108 & 27 & & & \\
\hline
\end{tabular}

Mezun olunan lisans bölümüne göre belirlenen faktörlere yönelik tutumlarda farklılık olup olmadığını belirlemek amacıyla yapılan ANOVA sonuçları ise Tablo 7'de verilmiştir. Buna göre sadece bilinçli tercih boyutu için görülen farklılık anlamlıdır (bilinçli tercih boyutu için $F=2,516$, $p=0,018$ ). Katılımcıların mezun oldukları lisans bölümüne göre yapılan ANOVA sonuçlarında bilinçli tercih faktöründe görülen bu farklıığın hangi lisans bölümleri arasında olduğunu belirlemek amacıyla Tablo 8' de açıklanan Tukey çoklu karşılaştırma testi uygulanmıştır.

Tablo 7: Mezun Olunan Lisans Bölümüne Göre Tek Yönlü ANOVA Sonuçları

\begin{tabular}{|c|c|c|c|c|c|c|}
\hline Faktörler & Varyans Kaynağı & $\begin{array}{c}\text { Kareler Top- } \\
\text { lamı }\end{array}$ & s.d. & $\begin{array}{c}\text { Kareler Or- } \\
\text { talaması }\end{array}$ & $\mathrm{F}$ & $p$ \\
\hline \multirow{3}{*}{ Eğitim Etkinliği } & Gruplar Arası & 5,786 & 7 & 0,827 & 0,819 & 0,573 \\
\hline & Gruplar İçi & 135,214 & 134 & 1,009 & & \\
\hline & Toplam & 141,000 & 141 & & & \\
\hline \multirow{3}{*}{ İletişim } & Gruplar Arası & 1,481 & 7 & 0,212 & 0,203 & 0,984 \\
\hline & Gruplar İçi & 139,519 & 134 & 1,041 & & \\
\hline & Toplam & 141,000 & 141 & & & \\
\hline \multirow{3}{*}{ Bilinçli Tercih } & Gruplar Arası & 16,377 & 7 & 2,340 & 2,516 & 0,018 \\
\hline & Gruplar İçi & 124,623 & 134 & 0,930 & & \\
\hline & Toplam & 141,000 & 141 & & & \\
\hline \multirow{3}{*}{ Yeterlilik } & Gruplar Arası & 12,624 & 7 & 1,803 & 1,882 & 0,077 \\
\hline & Gruplar İçi & 128,376 & 134 & 0,958 & & \\
\hline & Toplam & 141,000 & 141 & & & \\
\hline \multirow{3}{*}{ Gelir ve Yeterlilik } & Gruplar Arası & 4,819 & 7 & 0,688 & 0,677 & 0,691 \\
\hline & Gruplar İçi & 136,181 & 134 & 1,016 & & \\
\hline & Toplam & 141,000 & 141 & & & \\
\hline
\end{tabular}


Ağustos 2019, C. 14, S. 2

Tablo 8: Mezun Olunan Lisans Bölümüne Göre Tukey Testi Sonuçları

\begin{tabular}{|c|c|c|c|c|c|}
\hline $\begin{array}{l}\text { Bağımlı } \\
\text { Değişken }\end{array}$ & (I) Lisans & (J Lisans) & $\begin{array}{l}\text { Ortalama } \\
\text { Fark (I-J) } \\
\end{array}$ & Std. Hata & $\mathrm{p}$ \\
\hline \multirow{49}{*}{ 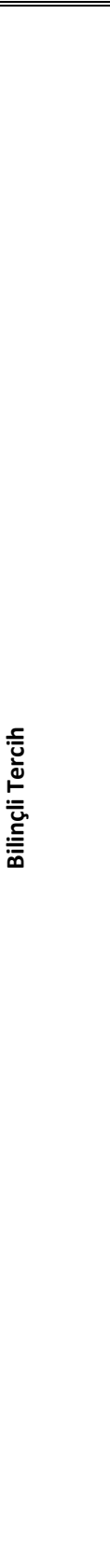 } & \multirow[t]{7}{*}{ Elektrik Mühendisliği } & Elektronik Mühendisliği & $-1,2069$ & 0,7470 & 0,740 \\
\hline & & Makine Mühendisliği & 0,3314 & 0,3302 & 0,973 \\
\hline & & İnşaat Mühendisliği & $-0,2688$ & 0,4312 & 0,999 \\
\hline & & Bilgisayar Mühendisliği & $-0,0216$ & 0,7470 & 1,000 \\
\hline & & Endüstri Mühendisliği & 0,0746 & 0,4574 & 1,000 \\
\hline & & Elektrik Elektronik Müh. & 0,3614 & 0,3427 & 0,965 \\
\hline & & Diğer & 1,0013 & 0,3992 & 0,201 \\
\hline & \multirow[t]{7}{*}{ Elektronik Mühendisliği } & Elektrik Mühendisliği & 1,2069 & 0,7470 & 0,740 \\
\hline & & Makine Mühendisliği & 1,5384 & 0,6935 & 0,348 \\
\hline & & İnşaat Mühendisliği & 0,9381 & 0,7470 & 0,913 \\
\hline & & Bilgisayar Mühendisliği & 1,1853 & 0,9643 & 0,922 \\
\hline & & Endüstri Mühendisliği & 1,2816 & 0,7624 & 0,699 \\
\hline & & Elektrik Elektronik Müh. & 1,5684 & 0,6996 & 0,334 \\
\hline & & Diğer & 2,2083 & 0,7289 & 0,057 \\
\hline & \multirow[t]{7}{*}{ Makine Mühendisliği } & Elektrik Mühendisliği & $-0,3314$ & 0,3302 & 0,973 \\
\hline & & Elektronik Mühendisliği & $-1,5384$ & 0,6935 & 0,348 \\
\hline & & İnşaat Mühendisliği & $-0,6002$ & 0,3302 & 0,609 \\
\hline & & Bilgisayar Mühendisliği & $-0,3531$ & 0,6935 & 1,000 \\
\hline & & Endüstri Mühendisliği & $-0,2568$ & 0,3637 & 0,997 \\
\hline & & Elektrik Elektronik Müh. & 0,0299 & 0,2012 & 1,000 \\
\hline & & Diğer & 0,6698 & 0,2871 & 0,284 \\
\hline & \multirow[t]{7}{*}{ İnşaat Mühendisliği } & Elektrik Mühendisliği & 0,2688 & 0,4312 & 0,999 \\
\hline & & Elektronik Mühendisliği & $-0,9381$ & 0,7470 & 0,913 \\
\hline & & Makine Mühendisliği & 0,6002 & 0,3302 & 0,609 \\
\hline & & Bilgisayar Mühendisliği & 0,2471 & 0,7470 & 1,000 \\
\hline & & Endüstri Mühendisliği & 0,3434 & 0,4574 & 0,995 \\
\hline & & Elektrik Elektronik Müh. & 0,6302 & 0,3427 & 0,595 \\
\hline & & Diğer & $1,2701 *$ & 0,3992 & 0,038 \\
\hline & \multirow[t]{7}{*}{ Bilgisayar Mühendisliği } & Elektrik Mühendisliği & 0,0216 & 0,7470 & 1,000 \\
\hline & & Elektronik Mühendisliği & $-1,1853$ & 0,9643 & 0,922 \\
\hline & & Makine Mühendisliği & 0,3531 & 0,6935 & 1,000 \\
\hline & & İnşaat Mühendisliği & $-0,2471$ & 0,7470 & 1,000 \\
\hline & & Endüstri Mühendisliği & 0,0962 & 0,7624 & 1,000 \\
\hline & & Elektrik Elektronik Müh. & 0,3831 & 0,6996 & 0,999 \\
\hline & & Diğer & 1,0229 & 0,7289 & 0,854 \\
\hline & \multirow[t]{7}{*}{ Endüstri Mühendisliği } & Elektrik Mühendisliği & $-0,0746$ & 0,4574 & 1,000 \\
\hline & & Elektronik Mühendisliği & $-1,2816$ & 0,7624 & 0,699 \\
\hline & & Makine Mühendisliği & 0,2568 & 0,3637 & 0,997 \\
\hline & & İnşaat Mühendisliği & $-0,3434$ & 0,4574 & 0,995 \\
\hline & & Bilgisayar Mühendisliği & $-0,0962$ & 0,7624 & 1,000 \\
\hline & & Elektrik Elektronik Müh. & 0,2868 & 0,3751 & 0,995 \\
\hline & & Diğer & 0,9267 & 0,4274 & 0,378 \\
\hline & \multirow[t]{7}{*}{ Elektrik Elektronik Müh. } & Elektrik Mühendisliği & $-0,3614$ & 0,3427 & 0,965 \\
\hline & & Elektronik Mühendisliği & $-1,5684$ & 0,6996 & 0,334 \\
\hline & & Makine Mühendisliği & $-0,0299$ & 0,2012 & 1,000 \\
\hline & & İnşaat Mühendisliği & $-0,6302$ & 0,3427 & 0,595 \\
\hline & & Bilgisayar Mühendisliği & $-0,3831$ & 0,6996 & 0,999 \\
\hline & & Endüstri Mühendisliği & $-0,2868$ & 0,3751 & 0,995 \\
\hline & & Diğer & 0,6398 & 0,3015 & 0,406 \\
\hline
\end{tabular}


Tablo 8'deki Tukey testi sonuçlarına göre, bilinçli tercih faktörü açısından anlamlılık gösteren söz konusu farklılığın İnşaat Mühendisliği bölümü ile Diğer kategorisi altında toplanan mühendislikler arasındaki görüş farklılığından kaynaklandığı görülmektedir. Bu sonuçlar incelendiğinde, İnşaat Mühendisliği bölümünden mezun olan katılımcıların Diğer kategorisi altında toplanan mühendisliklerden mezun olan mühendislere göre bilinçli tercih faktörüne yönelik daha kararlı bir tutum sergiledikleri görülmektedir. Başka bir ifadeyle İnşaat Mühendisliğinden mezun olan katılımcıların Diğer kategorisi altında toplanan mühendisliklerden mezun olan mühendislere kıyasla mezun oldukları bölümlere başvururken daha bilinçli bir şekilde davrandıkları anlaşılmaktadır.

\section{Sonuç}

Nitelikli insan gücünün önemine bağlı olarak bu çalışmada, nitelikli insan yetiştiren kurumlar arasında önemli bir rolü olan mühendislik fakülteleri ve bu fakültelerden mezun olmuş mühendislerin iş hayatında edindiği tecrübeler ve karşılaştıkları zorluklar incelenmiştir. Bununla birlikte mezun mühendislerin lisans döneminde aldıkları teorik ve uygulamalı eğitimlerin piyasada ne derece karşılık bulabildiği, yine mühendislerin kendi bakış açılarıyla ortaya konmaya çalışımıştır. Ayrıca lisans eğitimi öncesinde (orta öğretim döneminde) aldıkları veya almaları gereken eğitimlere yönelik de mezun mühendislerin görüşlerine başvurulmuştur.

\section{Çalışma neticesinde elde edilen bulgular ve çözüm önerileri;}

Cinsiyete göre alt ölçeklerin bağımsız örneklemler $t$ testi sonuçları incelendiğinde sadece yeterlilik alt ölçeği bakımından cinsiyete göre erkek ve kadın mezunlar arasındaki fark anlamlı bulunmuştur (yeterlilik boyutu için ortalama fark=0,49303909 ve $p=0.041$ ). Oluşan bu farklılığı anlamaya yönelik olarak yeterlilik faktörünün alt maddeleri incelendiğinde; "Çalışmaya ilk başladığımda belirli bir süreyle uygulama alanında çalışmakta olan (Ustabaşı, Usta vs.) personelden yardım almak durumunda kaldım." maddesine, erkek mezunların ortalama 3,98 puan, kadın mezunların ise ortalama 3,50 puan verdikleri görülmektedir. Destekleme oranları birbirine yakın olmasına karşın, erkek mezunların desteleme oranının biraz daha fazla olması; erkek mezunların kadınlara nazaran daha çok uygulama alanında çalışması, dolayısıyla, ustabaşı ve usta gibi saha elemanları ile birlikte daha çok çalışmalarıyla açıklanabilir. Bununla birlikte; "Eğitim Etkinliği", "iletişim", Bilinçli Tercih" ve "Gelir ve Yeterlilik" alt ölçeklerinde cinsiyete göre kadın ve erkekler arasında anlamlı bir fark bulunamamıştır.

Yukarıda bahsi geçen ustabaşı ve ustalar; işletmelerde ağırlıklı olarak uygulama elemanı olarak üretim alanında çalışmakta olup belirli bir sistem veya alanda uzun yıllar çalışmaları nedeniyle, işletmelerin sistem ve faaliyetlerine yönelik tecrübe ve bilgi bakımından oldukça donanımlıdırlar. Bu durum, belirli bir alanda uzmanlaşmanın olumlu sonuçları arasındadır. Bununla birlikte, yeni mezun olarak bir işletmede görev alan mühendisler ise; aldıkları teorik eğitimlerin hem işletme özelindeki üretim, sistem ve faaliyetlerle tam örtüşmemesi, hem de uygulamaya yönelik tecrübesizlikleri nedeniyle uygulama alanına ilk planda uzak kalabilmektedirler. Bunun bir sonucu olarak da ustabaşı veya ustalardan yardım almadan sahadaki faaliyetlere etkin bir şekilde müdahil olmakta zorlandıkları söylenebilir.

Bununla birlikte yeterlilik faktörü altında bulunan "Daha iyi işletme ve pozisyonlarda çalışmam için bölümümde aldığım eğitimin yanı sıra ilave bir eğitim almam gerektiğine inanıyorum" ifadesini erkek mühendislerin 4,34 ve kadın mühendislerin 3,85 ortalama ile çok yüksek ve yüksek oranda destekledikleri dikkate alındığında; mezun mühendislerin sistem içerisinde kaybolan 
ve ancak sisteme ayak uydurabilen istihdamlar olmak yerine, sistemi kontrolü altında alıp geliştirebilecek vizyon sahibi mühendisler olma noktasında zorlandıkları söylenebilir.

Oluşan bu durumu anlamaya yönelik mühendislik bölümlerindeki müfredatlar incelendiğinde; dört yıllık eğitim süresinin ilk iki yılındaki ortak veya genel derslerin (matematik, fizik, kimya, dil bilgisi, vb.) oranları, toplam eğitim süresi dikkate alındığında, yüksek sayılabilir. Geriye kalan iki senelik süreç içerisindeki mühendislik ders ve uygulamalarını öğrencinin tam anlamıyla kavrayıp benimsemesi ise zorlaşmaktadır. Bununla birlikte, anket sonuçları (daha iyi işletme ve pozisyonlarda çalışmam için bölümümde aldığım eğitimin yanı sıra ilave bir eğitim almam gerektiğine inanıyorum ifadesini destekleme oranı erkeklerde 4,34, kadınlarda 3,85) doğrultusunda bir değerlendirme yapıldığında; teori ve uygulamaya yönelik ders veya programların ihtiyacı yeterli seviyede karşılayamadığı söylenebilir. Bu çerçevede bir değerlendirme yapıldığında;

- Genel veya ortak ders (matematik, fizik, kimya, dil bilgisi, vb.) öğreniminin orta öğretim döneminde tamamlanarak dört yıllık mühendislik süresinin büyük oranda ilgili mühendislik alanına yönelik ders ve uygulamaları içerecek şekilde düzenlenmesi; ihtiyaç duyulması durumunda orta öğretim süresinin uzatılması,

- Mühendislik eğitiminin son yılında öğrencinin çalışmak istediği alanda uzmanlaşmasının yolunu açabilecek seçmeli ders ve saha örnekleri noktasında bilinçlendirilmesi,

- Uygulamaya yönelik derslerin bir bölümünün işletme ortamında yapılması sağlanarak, öğrenciye; ilgili bölümde öğrendiği teorik dersleri sahada direk test ve tecrübe fırsatı verilmesi ve teknolojik gelişmeleri yakından takip ederek piyasa ihtiyaçlarına göre kendilerini geliştirip güncellemesi, eğitim sürecinin etkinliğine katkı sunabilecek öneriler olarak verilebilir.

Türkiye'de eğitim veren mühendislik fakültelerinden mezun olan mühendisler ağırlıklı olarak uygulama mühendisi olarak sahada (üretim, bakım, yönetim) görev yapmaktadırlar. Ancak, teknolojik gelişmelerin özellikle AR-GE faaliyetleri kapsamında ortaya çıkması, bu alanda görev yapabilecek, alana hakim ve araştırmaya yatkın mühendislerin yetişmesini ihtiyaç haline getirmiştir. Bu anlamda da mühendislik fakültelerinin ilgili bölümlerinde, Araştırma ve Geliştirme (ARGE)'ye yönelik bir müfredat oluşturularak alan kapsamında AR-GE Mühendisleri yetiştirilebilir.

Mezun olunan liseye göre alt ölçeklerin bağımsız örneklemler t Testi sonuçları incelendiğinde; sadece iletişim ve bilinçli tercih alt ölçekleri bakımından, Mesleki Eğitim veren Lise (MEL) ve Fen/Anadolu/Anadolu Öğretmen Lisesi vb. (FAL) liseleri arasındaki fark anlamlı bulunmuştur (iletişim boyutu için ortalama fark $=-0,59602464$ ve $p=0,004$, bilinçli tercih boyutu için ortalama fark $=0,66765897$ ve $p=0,001$ ). Ortaya çıkan bu farklılığı açıklamaya yönelik olarak sırasıyla iletişim faktörü alt maddeleri incelendiğinde; ifade 15'de belirtilen; "Bölümümde aldığım eğitim ile insanlarla olan iletişim kabiliyetimi geliştirdiğimi düşünüyorum" maddesine katılımcılar 2,68 ve 3,33 puanlar vererek kararsız kalmışlardır. Sonuç olarak katılımcıların tamamının bölümlerinde aldıkları iletişime yönelik eğitimlerin etkinliği noktasında olumsuz düşünce içerisinde olmadıkları görülmekle birlikte, konuya yönelik pozitif görüşlerinin de olmadığı anlaşılmaktadır.

Bu doğrultuda bir değerlendirme yapıldığında mühendislik fakültelerinden mezun olan mühendislerin teknik, teorik ve uygulama tecrübesi açısından yeterli donanıma sahip olması, sahaya yönelik başarı için önemlidir. Ancak, teknik ve yönetsel görevleri nedeniyle, her düzeyde (kamusal ilişkiler, müşteriler, yabancı yatırımcılar, ustabaşı, usta, iş̧̧i vb.) iletişime yönelik bilgi, tecrübe, öngörü, genel kültür ve iletişim tekniklerine (etkili konuşma, ikna kabiliyeti, güven verebilme vb.) sahip olması da, orta ve uzun vadede başarılı olma ve piyasada tutunma açısından 
önem arz etmektedir. İşverenler açısından değerlendirildiğinde ise, bahsedilen niteliklere sahip bir mühendisin insan kaynakları yönetimi ve stratejisi açısından çarpan etkisi oldukça yüksek olabilecektir.

Hemen her alanda öneminden bahsettiğimiz küreselleşme ve küresel pazar/ pazarlama nedeniyle, uluslararası iletişim de önem kazanmış; ulusal alanda bile etkin bir şekilde rekabet edebilmenin önemli bir parametresi haline gelmiştir. Bu durumda iletişim kavramını, yabancı dil bilgisi ile de ele almak gerekmektedir. Bu anlamda öncelikle, Türkiye'de mühendislik eğitimi veren fakültelerin yabancı dil eğitiminin etkinliği değerlendirilip; iletişimin bir faktörü olarak yabancı dil eğitimi, teknik ve sosyal yönleri açısından etkin bir şekilde öğretilerek, stajların bir bölümünün yabancı dilin konuşulduğu bir ülkede yaptırılması sağlanabilir. Bununla birlikte mühendislik fakültelerine girişte belirli bir seviyede yabancı dil bilgisi olması şartı konularak, alana yönelik yabancı dilin teknik boyutu da daha etkin bir şekilde öğretilebilir.

Mezun olunan liseye göre alt ölçeklerin bağımsız örneklemler t Testi sonuçları incelendiğinde anlamlı farklılık gösteren diğer bir alt ölçek ise, bilinçli tercih faktörüdür (ortalama fark=0,66765897 ve $p=0,001$ ). Meydana gelen bu farklılığı açıklamaya yönelik bilinçli tercih alt maddeleri sırasıyla incelendiğinde; "Mesleğin özellikleri ve içeriği hakkında daha önceden bilgim vardı" maddesini mesleki eğitim veren bir liseden mezun olmuş mühendisler (MEL) 4,39 puanla çok yüksek oranda, Fen/Anadolu/Anadolu Öğretmen vb. liselerden (FAL) mezun olan mühendisler ise 3,85 oranla yüksek oranda destekledikleri görülmektedir. Aynı faktör altındaki ifade 1'de belirtilen; "Bölümüme bilinçli bir tercihle girdim" maddesini ise MEL'den mezun olan mühendisler 4,54 puanla çok yüksek oranda, FAL'dan mezun olan mühendislerin ise 3,91 puanla yüksek oranda destekledikleri görülmektedir. MEL'den mezun olan mühendislerin destekleme oranın, FAL'dan mezun olan mühendislere göre fazla olmasının nedeni; MEL'den mezun olan mühendislerin ağırlıklı olarak orta öğretimdeki mesleki bölümlerine yönelik mühendisliği tercih etmesi ile açıklanabilir.

Bununla birlikte bilinçli tercih konusu, üzerinde durulması gereken önemli bir husustur. Bilinçli Tercih faktöründe ortaya çıkan durumu, Gelir ve Yeterlilik faktörü ile birlikte analiz etme, konunun anlaşılmasına katkı sunacaktır. Bu anlamda, Gelir ve Yeterlilik alt maddesi incelenecek olursa; " Orta Öğretim (lise) döneminde, ilgili yükseköğretim alanına yönelik olarak temel uygulamalı ve teorik dersleri almak yükseköğretimdeki başarıyı artıracaktır" maddesini, MEL'den mezun mühendisler 4,50 ve FAL'dan mezun mühendisler 4,36 ortalama ile puanlayarak çok yüksek oranda desteklemişlerdir. MEL'den mezun olmuş mühendislerin bu duruma çok yüksek oranda destek vermesi; mühendislik öncesi, ilgili mühendislik bölümü ile ilgili eğitim almış olmanın avantajlarından yararlanmaları; FAL'dan mezun olmuş mühendislerin çok yüksek oranda destek vermeleri ise kendilerini ilgili mühendislik ders ve uygulamalarına hazırlıksız olarak görmeleri ile açıklanabilir.

Bu kapsamda, mühendislik fakültelerine öğrenci kaynağı teşkil etmeleri ve bilinçli tercihe yönelik etkin bir değerlendirme yapmaya yönelik orta öğretimde alınan eğitimlerin ve orta öğretim sisteminin genel anlamda değerlendirilmesi yapılabilir.

Sonuç olarak bu çalışmada nitelikli insan kavramı ele alınmış, bu çerçevede, nitelikli insan yetiştiren kurumlar arasında önemli bir rolü olan mühendislik fakülteleri ve bu fakültelerden mezun olmuş mühendisler incelenmiştir. Yukarıda bahsedilen analizler, ankete katılan 142 adet mühendisin görüşlerinin analiz edilmesiyle elde edilmiştir. Bu doğrultuda yapılacak çalışmalarda daha fazla mühendise ulaşılarak veri toplanması durumunda, elde edilen sonuçların sağlaması yapılabilecektir. Bununla birlikte, kamu-özel, yurt içi-yurt dışı eğitim ve yabancı dil bilgisi 
Ağustos 2019, C. 14, S. 2

karşılaştırması yapılarak bu çalışmaya esas teşkil eden konu farklı boyutlardan incelenebilecek; elde edilen sonuçlar karşılaştırılarak daha kapsamlı analizler yapılabilecektir. 


\section{Kaynaklar}

Altın, Mustafa; Uğur, Latif Onur; Bekem, İlknur (2010), “Meslek Yüksekokulları İnşaat Teknolojisi Programı Müfredatlarının ve Eğitim Donanımlarının Değerlendirilmesi: Selçuk Üniversitesi Teknik Bilimler Meslek Yüksekokulu Örneği”, International Conference on New Trends in Education and Their Implications, 11-13 Kasım, Antalya-Turkey.

Bai, Limin (2006). "Graduate Unemployment: Dilemmas and Challenges in China's Move to Mass Higher Education", Cambridge University Press, The China Quarterly, No. 185: 128-144.

Besleme, Mehmet (2006), "Çalışan Kimya Mühendislerinin Kimya Mühendisliği Eğitimine iliş̧kin Taleplerinin Analizi”, Gazi Üniversitesi Fen Bilimleri Enstitüsü, Basılmamış Yüksek Lisans Tezi, Ankara.

Bloom, Andreas; Saeki, Hiroshi (2011), "Employability and Skill Set of Newly Graduated Engineers in India”, Policy Research Working Paper, April 2011, Rapor No: WPS5640.

Durak, Gökhan (2009), “Üniversitelerde Verilen Muhasebe Eğitiminin Kırklareli Yöresinde Faaliyet Gösteren Küçük ve Orta Büyüklükteki İşletmelerin Beklentilerini Karşılama Düzeyinin İncelenmesi”, Trakya Üniversitesi Sosyal Bilimler Enstitüsü, Basılmamış Yüksek Lisans Tezi, Edirne.

Düzakın, Erkut; Yılmaz, Özgün (2009), "İşletme Mezunlarının İş Hayatındaki Yeri ve İşletme Eğitimi: 1000 Büyük Sanayi Kuruluşunun İşletme Mezunlarından Beklentileri Üzerine Araştırma”, Ç.Ü. Sosyal Bilimler Enstitüsü Dergisi, C. 18, S. 1: 149-164.

Elshorbagy, Amin; Schönwetter, Dieter J (2002), “Engineer Morphing: Bridging the Gap Between Classroom Teaching and the Engineering Profession", International Journal of Engineering Education, Vol. 18 No. 3: 295-300.

Gençoğlu, Muhsin T; Gençoğlu, Eda (2005), "Mühendislik Lisans Eğitimi ve Başarı Ölçütleri”, TMMOB Mühendislik Eğitimi Sempozyumu, Gazi Üniversitesi Mühendislik Mimarlık Fakültesi Kongre Merkezi, Ankara, 2005: 271-280.

Göral, Ahmet (2008), "İş Çevrelerinin Meslek Eğitim Merkezlerinden Beklentileri ve Meslek Eğitim Merkezlerinin Bu Beklentileri Karşılama Düzeyi”, Yedi Tepe Üniversitesi Sosyal Bilimler Enstitüsü, Basılmamış Yüksek Lisans Tezi, İstanbul.

Grant Haworth, Jennifer; Conrad, Clifton F. (1997), “Emblems of Quality in Higher Education: Developing and Sustaining High-Quality Programs”, ISBN: ISBN-0-205-19546-6, ERiC Number: ED409804.

İçli, Gülnur (2007), “işletmelerin Meslek Yüksek Okulu Mezunları ile ilgili görüşleri ve Beklentileri (Lüleburgaz ilçe sınırları içerisinde faaliyet gösteren işletmeler üzerine bir araştırma)", Marmara Üniversitesi iktisadi ve Idari Bilimler Fakültesi (i.i.B.F) Dergisi, C. XXIII, S. 2: 263-272.

Lin, Z. Jun (2008), "A Factor Analysis on Knowledge and Skill Components of Accounting Education: Chinese Case", Advances in Accounting, incorporating Advances in International Accounting, Vol.24: 110-118.

Massie, J. Brett; Strang, Adam J; Ward, Rose Marie (2009), "Emloyer Perceptions of the Academic Preparation of EnrtryLevel Certified Athletic Trainers", Athletic Training Education Journal, Vol. 4, No. 2: 70-74.

Mustafa, Zabrikcam; Norkisme, Zainal Abidin; Suradi, Nur Riza Mohd; İsmail, Wan Rosmanira; Şahabuttin, F.F.A; Zaharim, Azami; Zalina, Mohd Ali (2008), "Engineering Education, Profession and Employer: Perception of Engineers in Electronic Sector", 5th WSEAS / IASME International Conference on Enginieering Education (EE'08), Heraklion, Greece, Temmuz 22-24: 355-359.

Sönmez, Murat (2011), “Mühendis ve Mühendis Yardımcılarının Yaşam Boyu Öğreniminde Meslek Yüksek Okullarının Rolü", Electronic Journal of Vocational Colleges, (Aralık 2011): 1-7.

Todd, Robert H.; Sorensen, Carl D; Magleby, Spencer P (1993), “Designing a Senior Capstone Course to Satisfy Industrial Customers", Journal of Engineering Education, Vol. 82 No. 2: 92-100. 